\title{
Augmented reality adoption intention among travel and tour operators in Malaysia: mediation effect of value alignment
}

\author{
Syed Shah Alam, Mohammad Masukujjaman, Samiha Susmit, Sumaiya Susmit and \\ Hassanuddeen Abd Aziz
}

\begin{abstract}
Purpose - This study evaluated the determinants of augmented reality (AR) adoption in Malaysia's travel and tour operator sectors through an integrated technology-organization-environmental (TOE) and diffusion of innovation (DOI) model.

Design/methodology/approach - The TOE and DOI were considered the primary theoretical models but are combined and extended by including few additional variables. Data were collected from 220 respondents of travel and tour operating businesses in Malaysia and analyzed by applying PLS structural equation model technique.

Findings - The empirical results established that perceived cost, relative advantages, complexity and compatibility, observability, competitor pressure, value alignment, customer pressure, and trialability are positively connected with the behavioral intention except for external support. The results reveal that value alignment partially mediates the association between relative advantages and behavioral intention, complexity and behavioral intention, compatibility and behavioral intention, perceived cost and behavioral intention except in between trialability and observability.

Originality/value - This research is unique as the value alignment construct is included in the model, and thus it fulfills the literature gap by adding the mediation construct. This study contributes to enhancing AR's understanding of the Malaysian travel and tour operator industry through the lenses of owners ormanagers. It offers an integrated model that combines the TOE and DOI models, rare in this sector, and can be replicated or extended with validated scales.
\end{abstract}

Keywords Augmented reality, Adoption intention, Retail store, TOE, DOI

Paper type Research paper

\section{Introduction}

Augmented reality (AR) is a computer-generated object that improves the real-world environment, offering context-sensitive information about the user's close surroundings in the combination of image, 3D models and immersive features using the technological appliance, that is, eyeglasses, a desktop, tablet and a smartphone (Yung and Khoo-Lattimore, 2017). It helps marketers market their products creatively (Ng and Ramasamy, 2018). At the same time, AR technology allows users to use it in the virtual and real world. AR technology enriches understanding by including virtual mechanisms such as graphics, digital images or sensations as a novel interaction with the real world (Ng and Ramasamy, 2018). Considering the tremendous potential of AR technology, businesses adopt AR technology to interact with their customer, especially in the tourism sector.

AR's key applications in the tourism sector are seen in the pre-booking, information collecting process, the development of the on-site experience and buying of tourism goods and services,
Syed Shah Alam is based at the Universiti Kebangsaan Malaysia, Selangor, Malaysia. Mohammad Masukujjaman is based at the Northern University Bangladesh, Dhaka, Bangladesh. Samiha Susmit is based at the Universiti Kebangsaan Malaysia, Selangor, Malaysia. Sumaiya Susmit is based at the Universiti Teknologi Malaysia, Skudai, Malaysia. Hassanuddeen Abd Aziz is based at the International Islamic University Malaysia, Kuala Lumpur, Malaysia.

Received 17 March 2021 Revised 13 September 2021 30 September 2021 Accepted 20 December 2021

(C) Syed Shah Alam, Mohammad Masukujjaman, Samiha Susmit, Sumaiya Susmit and Hassanuddeen Abd Aziz. Published in Journal of Tourism Futures. Published by Emerald Publishing Limited. This article is published under the Creative Commons Attribution (CC BY 4.0) licence. Anyone may reproduce, distribute, translate and create derivative works of this article (for both commercial and non-commercial purposes), subject to full attribution to the original publication and authors. The full terms of this licence may be seen at http:// creativecommons.org/licences/ by/4.0/legalcode. 
seeking and investigating feedback (Ukpabi and Karjaluoto, 2016). AR has been stated to help upsell hotel reservations, travel and tourist attractions to the booking process. It generates emotional connections relative to conventional media such as brochures and videos due to the immediate rapport established between the firm and visitors (Olsson et al., 2013). By modernizing the current offering, AR adds value, and, in exchange, this is intended to exhibit it as more appealing to new markets and maintain existing ones. He et al. (2018) confirmed that embracing AR in the tourism destination would boost buyers' attitudes, optimize their mood and enhance positive behavioral purpose. AR enables visitors to visit new areas, delivering valuable and fascinating knowledge to enrich their experience and capture and retain tourists' attention. However, for tourism suppliers to stay competitive and appealing to modern visitors and resolve spillovers, they must adopt AR in their business.

Although the benefit of applying AR in travel and tourism is not deniable, research shows that Malaysians are slow in adopting new technology ( $\mathrm{Ng}$ and Ramasamy, 2018). According to Lazim and Rahman (2015), retail, tourism, gaming and other sectors slowly adopt AR technology. Malaysian branches of some international companies are applying AR technology for marketing purposes. In both products and services-based, Malaysian companies apply AR technology to market their products and services ( $\mathrm{Ng}$ and Ramasamy, 2018). Therefore, the usage of AR technology in the tourism sector is much smaller. Malaysian industries have to accept AR technology, which is part of the Fourth Industrial Revolution; otherwise, the Malaysian economy will be slower to their economic development. According to Zulkifli et al. (2016), only 44\% of Malaysians are familiar with Malaysia's AR technology. Therefore, an effort is needed to enrich our understanding of the AR adoption process that has to be discovered.

Previous research has investigated the importance of AR for tourism from several viewpoints, for instance, cross-cultural (Jung et al., 2018), stakeholder (tom Dieck and Jung, 2017), unique experience creation (Tussyadiah et al., 2018), organizational (Cranmer et al., 2016), tourist (tom Dieck et al., 2016) and business model (Cranmer et al., 2018). Such studies indicate that the implementation of AR in tourism will produce enhanced interactions and boost visitors' perceptions and behavioral intentions (He et al., 2018). AR's implementation is also deemed essential for market profitability, creativity and enhancement of existing goods and services (Hassan and Rahimi, 2016). Nonetheless, studies investigating the importance of AR with a particular emphasis on the tourism suppliers' viewpoint are rare. In particular, why Malaysian tourism suppliers have struggled in the diffusion of AR technologies rapidly remains untouched.

Numerous studies applied diffusion of innovation (DOI) theory at the firm-level technology adoption context, which shows that innovation diffusion is mainly based on the system's technological factors and users' insights (Al-Zoubi, 2013). Other external factors such as competitive pressure, customer pressure and external support may affect adoption decisions for AR technology in an organizational context (Al-Zoubi, 2013). Likewise, using the technology-organizationenvironmental (TOE) model may be plausible in this research context. Researchers argued that combinations of these models provide comprehensiveness in adoption research (Piaralal et al., 2015). Past studies combined the theories to examine the adoption of an enterprise system (Ramdani et al., 2009), cloud computing (Alshamaila et al., 2013) and broadband mobile (Chiu et al., 2017). According to Thong (1999), information technology and its characteristics are changing very fast; therefore, it is not appropriate to use a single theoretical model. Researchers argued that to understand complicated technology better, it would be essential to combine more than one theoretical model (Oliveira and Martins, 2011). Therefore, we combined both DOI and TOE theory and developed an integrated model (Figure 1).

The current research contributes by applying two factors theory in examining the technological and environmental factors to a better and more in-depth understanding of AR's adoption intention in the travel and tour-operating sector, especially in Malaysian perspectives. So far, the combined model of DOI and TOE to study AR's adoption from the tourism perspective is rare. Chandra and Kumar (2018) integrated both the models but only used a single construct (relative advantages) in e-commerce industry perspectives. The present study used all the constructs of DOI in the tourism 


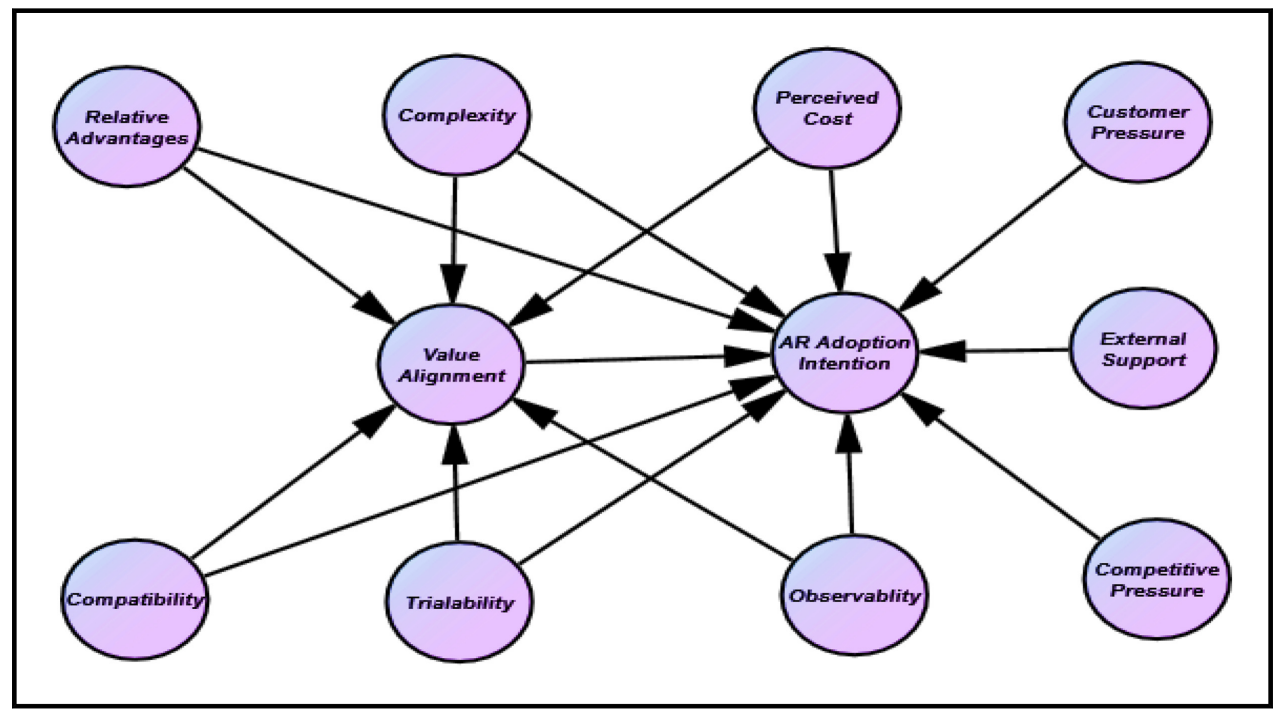

context. Besides, the study contributes to offering value alignment in the model as a mediator, which will help reduce knowledge gaps in the literature. Thus, this will enrich the body of knowledge with the empirical results for future replications.

\section{Literature review}

\subsection{Empirical study on $A R$ in tourism and entertainment industry}

The application of AR has been used in many tourism and hospitality industries. Do et al. (2020) researched mobile AR apps in tourism and found enjoyment and satisfaction as significant factors for their adoption. Kourouthanassis et al. (2015) studied AR in tourists in Greece, where they found pleasure, arousal, dominance, personal innovativeness and price value are a predictors of adoption. There have been studies on entertainment study researched on AR technology in the entertainment industry. Li et al. (2020) explored perceived benefits; satisfaction and perceived risk affect buying intention. Likewise, Shin (2019) found that immersion, social presence, confirmation, utility, hedonism and satisfaction are significant factors in knowing the behavioral intention of using AR (Appendix).

\subsection{Theoretical background}

Researchers categorized adoption into corporate, group/team and individual levels (Liu et al., 2008). The theories like theory of planned behavior (TPB), theory of reasoned action (TRA), unified theory of acceptance and use of technology (UTAUT), although they are used for individual-level research, are less accepted in an organizational context (Oliveira and Martins, 2011; Liu et al., 2008). In contrast, DOI and TOE are widely used to examine technology adoption in an organizational context (Gangwar et al., 2014; Al-Zoubi, 2013).

2.2.1 TOE and DOI model. TOE stands on the three main facets (e.g. technological, organizational and environmental) affecting a firm's innovative technology adoption - matching our research objectives, three reasons for taking TOE for this study. Firstly, it is an advanced model integrated with the environmental construct, whereas the DOI framework is constructed from the technology and organizational perspective to explain innovation adoption (Gangwar et al., 2014). T-O-E framework is more holistic and size and industry friendly offers sound theoretical foundation and empirically validated in previous study (Hwang et al., 2015). The TOE model has been applied in the 
tourism literature in various settings, including reservation system hotel adoption (Wang et al., 2016), e-commerce use (Chang et al., 2015), the introduction of mobile technology into travel agencies (Lin, 2016) and the adoption in hospitality organizations of electrical customer service management (eCRM) systems (Racherla and Hu, 2008).

In contrast, Rogers (1962) summarized many studies in the area of the industry, medicine and anthropology and developed a model called diffusion of innovation (DOI) (Chiu et al., 2017). Rogers (1995) indicates that five main determinants of an innovation's perceived attributes explain $49-87 \%$ of the adoption rate variance. These five characteristics (relative advantage, compatibility, complexity, trialability and observability) are critical to innovation diffusion, success or failure (Rogers, 1995; Yang and Lee, 2019). Due to its robustness, the DOI model has been widely used in various areas of information technology adoption research, such as mobile enterprise applications (van den Berg and van derr Lingen, 2019), mobile banking (Al-Jabri and Sohail, 2012) and broadband mobile (Chiu et al., 2017). Apart from its robustness, it portrays only a direct relationship within the theoretical model (Plsek and Greenhalgh, 2001), limiting its reliance solely to predict complex behavior. According to Dibra (2015), Rogers' theory on DOI is the most suitable theoretical model for understanding factors that influenced the incorporation of sustainability in tourism businesses.

2.2.2 Conceptual model and constructs development. 2.2.2.1 Technological factors. The technological factors include cost, complexity (ease of use), compatibility; trialability, observability and relative advantage are as follows.

2.2.2.2 Perceived cost. Cost is one of the most critical factors affecting technology adoption (Alam et al., 2011). The cost of developing a program for AR, maintenance, and upgrade of website and availing the services to the consumers are the main costs incurred for web-based activities (Luarn and Lin, 2005). According to Hayes (2012), high cost is involved in technology implementation. Thereby small businesses are reluctant to use an IT-based program. Although high costs are involved in implementing IT, businesses without the latest technology go far behind their competitors in this digital era. Therefore, the following hypothesis is postulated:

H1. Perceived cost has a significant negative effect on AR technology adoption intention.

2.2.2.3 Relative advantage. According to Agarwal and Prasad (1997), the relative advantage is perceived as a firm's benefits compared to previously performing a similar task. Researchers identified that relative advantage is an essential predictor of innovation adoption and usage (Moghavvemi et al., 2012; Alam et al., 2011). In the context of the AR technology benefits, it would be predictable that online retailers who viewed AR technologies are beneficial would likely adopt AR technology. Based on the above discussion, we proposed the $\mathrm{H} 2$ :

H2. Relative advantage has a significant effect on the adoption intention of AR technology among online retailers.

2.2.2.3.1 Complexity. Lin and $\mathrm{Ho}(2010)$ define complexity as the innovation that is challenging to understand and complex to use. Rogers' complexity concept is comparable to Davis' perceived ease of use. It will decrease the adoption rate and negatively affect innovation adoption if it is not easy to use. Alam et al.'s (2011) study confirmed that ease of use significantly affects SMEs' ecommerce adoption intention. According to Selamat et al. (2009), people accept any technology when they find it easy to use. We expect that the adoption of AR technology is easy to use by online retailers. According to established empirical support and rationale, we hypothesize:

H3. Complexity (ease of use) has a significant effect on AR technology adoption intention among online retail store.

2.2.2.3.2 Compatibility. According to Rogers (1995), compatibility is the degree to which information technology innovation is viewed as compatible with the existing company's value, future adopters' needs and previous experience. Researchers found that compatibility positively affects Internet banking adoption intention (Kolodinsky et al., 2004) and information technology (Alam et al., 2011). The compatibility of new technology with the above idea either prompts or 
delays the organization's adoption rate. When online retailers find that the existing technology is compatible with AR technology, it is highly possible to adopt it. We propose the hypothesis based on the above discussion:

H4. Compatibility has a significant positive influence on the adoption intention of AR technology.

2.2.2.3.3 Trialability. According to Moore and Benbasat (1991), trialability is defined "as the degree to which it is possible to try using the IT innovation." Reducing the uncertainty of the technology trial facility may have a significant impact. According to Karahanna et al. (1999), the trialability possibility of innovation may reduce uncertainty and risk using new technology. The importance of trialability will decrease if the user experiences the technology (Moghavvemi et al., 2012). We assume that online retailers have the opportunity to try AR technology before adopting it. Based on the above rationale, we hypothesize:

H5. The trialability has a significant influence on online retailer's intention to adopt AR technology.

2.2.2.3.4 Observability. Observability refers to the idea that the functionality of using AR technology can be communicated to others, observed and measured (Moore and Benbasat, 1991). Usage of AR technology aims to allow customers to see the usability of the product from a different angle. The result will be viewed to customers; for example, using AR for the cloth-buying process, customers can try the dress virtually and see it from a different angle with a real-life feature. AR technology offers customers to try the product according to their needs to increase observability. According to Quinting et al. (2017), observability has a significant positive effect on technology adoption intention. Therefore, we develop the H6:

H6. Observability has a significant positive effect on the adoption intention of AR technology.

2.2.2.4 Environmental factors. Among the various environmental factors, competitive pressure, customer pressure and external support were chosen.

2.2.2.4.1 External pressure. Stakeholder pressure is one of the most essential predictors of innovation diffusion, comprising competitive pressure and customer pressure that affect information technology adoption intention among businesses. Researchers (El-Gohary, 2012; Wanyoike et al., 2012; Matikiti et al., 2018) found empirically that companies accept new technology when they find that other competitors are using the same technology. In contrast, the researchers identified that customer pressure among the significant stakeholder significantly influences enterprises' green adoption (Weng et al., 2015) and is a critical predictor of it (Zhang et al., 2020).

H7. Pressure from competitors significantly affects AR adoption intention.

H8. Pressure from customers significantly affects AR adoption intention.

2.2.2.4.2 External support. According to Ungan (2005), external support is considered the support that comes from outside the firm, and it will influence the firm's decision-making process, precisely when the company accepts new technology (Paydar et al., 2014). Wu and Subramaniam (2009) stated that the greater possibility of accepting new technology happens when support comes from the external body. According to Rogers (2003), expertise comes from a third party; a suitable policy of standard and powerful partners is the main body providing external support. Thus, we develop the hypothesis:

H9. External support has a significant positive effect on AR adoption intention.

2.2.2.5 Value alignment. According to Zhang et al. (2016), users accept innovation and technology if they find value and belief similar to their own. Yang and Lee (2019) found that value alignment can foster significant outcomes, including adoption intention. Kleijnen et al. (2009) stress that when users consider using innovation, relative advantage, compatibility and observability positively influence value creation. On the contrary, researchers such as Min and Kim (2015) and Calisir et al. (2014) confirmed that cost and complexity negatively affect value alignment. None of these studies identify whether value alignment mediates the relationship between relative advantage, 
compatibility, complexity, cost, trialability, observability and adoption intention. Only Yang and Lee (2019) tried to examine the mediating effect of these technological constructs and adoption intentions, and thus this study develops the following hypotheses:

H10. Value alignment has a significant effect on the adoption intention of AR technology among online retailers.

H11. Value alignment mediates the relationship between relative advantage and AR technology adoption intention.

H12. Value alignment mediates the relationship between complexity (ease of use) and AR technology adoption intention.

H13. Value alignment mediates the relationship between compatibility and AR technology adoption intention.

H14. Value alignment mediates the relationship between trialability and AR technology adoption intention.

H15. Value alignment mediates the relationship between observability and AR technology adoption intention.

H16. Value alignment mediates the relationship between cost and AR technology adoption intention.

\section{Research design and sample}

Data were collected from travel and tour operators based on the convenience sampling technique in Malaysia with help from our colleagues and students. The respondents for this study were the owners or top-level managers of the travel and tours operating SME businesses. These people involved in decision-making as it operates with fewer staff. We prepared a list of companies operating travel and tour operators in Malaysia through the Internet and sent them an email with a Google form link to fill up. From 360 emails sent, utilizing our personal influences where possible, we received 220 responses. Since the survey was conducted during COVID-19 pandemic (in January 2021), we could not conduct the paper-based survey. The online-based survey was used to confirm the respondents' anonymity and increase their responses (Richman et al., 1999). To reduce the chances of missing responses, an online questionnaire was developed in a way that respondents have to answer all questions.

\subsection{Measurement}

PEOU was measured from Alam et al.'s (2018) and Huang and Liao's (2015) study. The customer pressure scale was measured from the Wanyoike et al.'s (2012) study in this research. Competitor pressure was measured according to the study of Wanyoike et al. (2012). Attitude and behavioral intention scales were developed based on the studies of Alam et al. (2018) and Alam and Sayuti (2011). The cost was measured based on the study of Alam et al. (2011). External support was measured from the Paydar et al.'s (2014) study. All items in this research were modified to suit this research. This study's variables were measured using a 5-point Likert scale ranging from 1 = strongly disagree to 5 = strongly agree. All the constructs of this study were operationalized as reflective constructs.

\subsection{Common method bias}

According to Podsakoff et al. (2003), common method variance can be tested using a few techniques such as Harman's one-factor test, the respondents' confidentiality, clarity of items or questions and wording questions in reverse. This study used Harman's (1976) common method bias employing exploratory factor analysis. Assessing samples adequacy for factor analysis $\mathrm{KMO}$

PAGE 6 |JOURNAL OF TOURISM FUTURES $\mid$ VOL. $\mathbf{m}$ NO. ... 
(Kaiser-Meyer-Olkin) was used, and the results show that all the values were above 0.5 in the diagonal of the matrix and the $\mathrm{KMO}$ coefficient value was 0.848 . Moreover, an unrotated factor analysis technique was used to find that all factors loaded separately, and no single factor accounted for more than 50\%. These results indicate that there were 11 factors loaded with eigenvalues more than one, and the first factor explained about $38.7 \%$, and thus we can conclude that there is no issue of common method bias in this research. Lowry and Gaskin (2014) and Podsakoff et al. (2003) argued that there is a common method bias if a single factor explains more than $50 \%$ variance.

\subsection{Analysis of the data}

The proposed model of this study was tested using a Smart-PLS package of 3. Variance-based PLS-SEM (partial least square structural equation modeling) technique was used in the present study to test the hypotheses. According to Ringle et al. (2010), to determine the causal relationship in the most often Smart-PLS path modeling technique, direct and indirect relationships are used. PLS-SEM researchers can get a significant association rather than examining the goodness of fit of the model. Nowadays, PLS-SEM has gained massive attention from various research fields, including marketing, strategic management, operations management and human resource management (Ringle and Sarstedt, 2016). A two-step approach was used to test the model: (1) inner model or measurement model and (2) outer model or structural model (Ringle et al., 2005). In measuring the model, we checked the construct's validity and reliability, and the structural model determined the path coefficient and their significance.

\section{Measurement model analysis}

In this study, the measurement model is shown in Figure 2. Before testing the structural model, the measurement model was tested. Table 1 shows the outer loading, composite reliability values, Cronbach's alpha and average variance extracted (AVE).

\section{Figure 2 Measurement model}

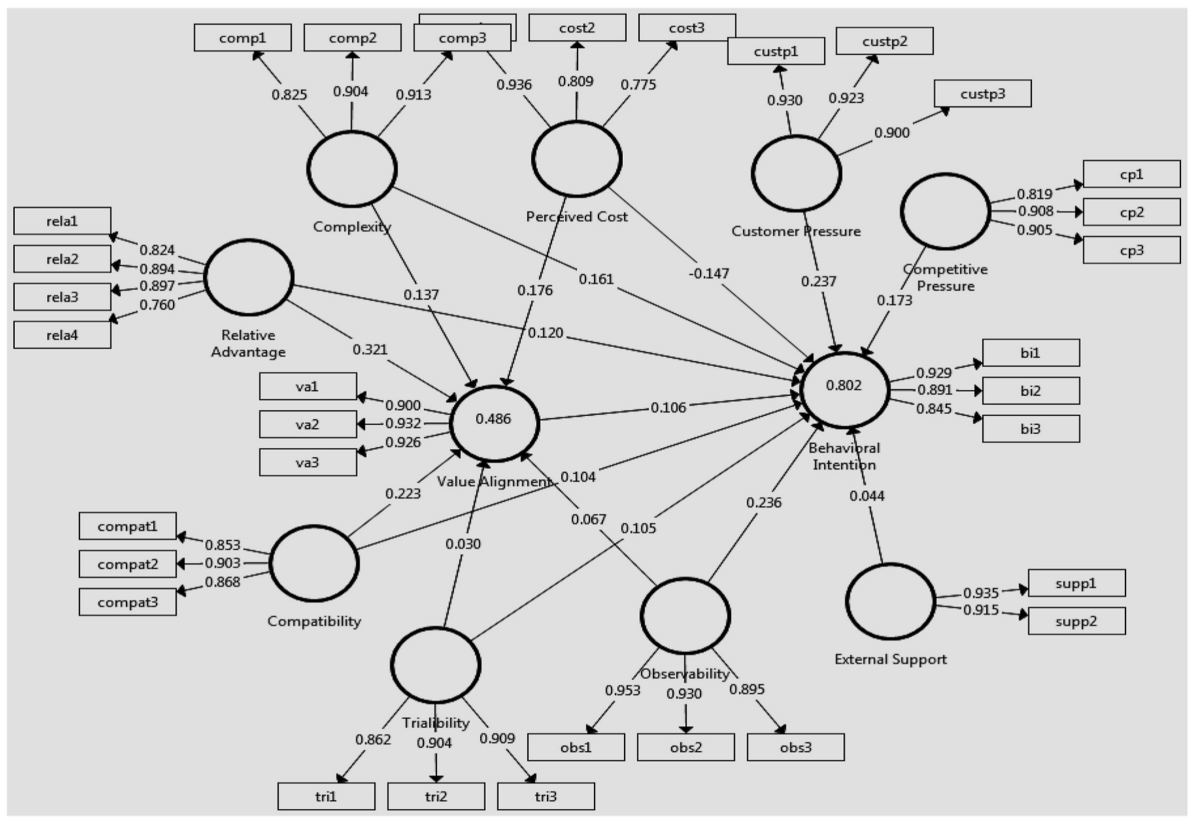


Table 1 Factor loadings and reliability statistics

\begin{tabular}{|c|c|c|c|c|c|c|c|c|}
\hline \multirow{2}{*}{ Constructs } & \multirow[b]{2}{*}{ Items } & \multirow[b]{2}{*}{ Loadings } & \multirow[b]{2}{*}{ AVE } & \multirow{2}{*}{$\begin{array}{c}\text { Composite } \\
\text { reliability }\end{array}$} & \multirow{2}{*}{$\begin{array}{c}\text { Cronbach's } \\
\text { alpha }\end{array}$} & \multirow[b]{2}{*}{ rho_A } & \multicolumn{2}{|c|}{ VIF } \\
\hline & & & & & & & $B l$ & $V A$ \\
\hline \multirow{3}{*}{$\begin{array}{l}\text { Behavioral } \\
\text { intention }\end{array}$} & bi1 & 0.929 & \multirow[t]{3}{*}{0.790} & \multirow[t]{3}{*}{0.919} & \multirow[t]{3}{*}{0.867} & \multirow[t]{3}{*}{0.871} & & \\
\hline & bi2 & 0.891 & & & & & & \\
\hline & bi3 & 0.845 & & & & & & \\
\hline \multirow{3}{*}{$\begin{array}{l}\text { Competitor } \\
\text { pressure }\end{array}$} & $\mathrm{cp} 1$ & 0.819 & \multirow[t]{3}{*}{0.771} & \multirow[t]{3}{*}{0.910} & \multirow[t]{3}{*}{0.853} & \multirow[t]{3}{*}{0.880} & \multirow[t]{3}{*}{1.508} & \\
\hline & $\mathrm{cp} 2$ & 0.908 & & & & & & \\
\hline & cp3 & 0.905 & & & & & & \\
\hline \multirow[t]{3}{*}{ Complexity } & Comp1 & 0.825 & \multirow[t]{3}{*}{0.778} & \multirow[t]{3}{*}{0.913} & \multirow[t]{3}{*}{0.856} & \multirow[t]{3}{*}{0.858} & \multirow[t]{3}{*}{1.493} & \multirow[t]{3}{*}{1.380} \\
\hline & Comp2 & 0.904 & & & & & & \\
\hline & Comp3 & 0.913 & & & & & & \\
\hline \multirow[t]{3}{*}{ Compatibility } & com1 & 0.853 & 0.766 & 0.908 & 0.847 & 0.851 & 1.885 & 1.691 \\
\hline & com2 & 0.903 & & & & & & \\
\hline & com3 & 0.868 & & & & & & \\
\hline Customer & custp & 0.930 & 0.842 & 0.941 & 0.906 & 0.908 & 2.479 & \\
\hline pressure & custp2 & 0.923 & & & & & & \\
\hline & custp3 & 0.900 & & & & & & \\
\hline External & es1 & 0.935 & 0.855 & 0.922 & 0.831 & 0.841 & 1.464 & \\
\hline support & es2 & 0.915 & & & & & & \\
\hline Observability & obs1 & 0.953 & 0.858 & 0.948 & 0.917 & 0.923 & 2.022 & 1.739 \\
\hline & obs2 & 0.930 & & & & & & \\
\hline & obs3 & 0.895 & & & & & & \\
\hline Perceived & pc1 & 0.936 & 0.710 & 0.879 & 0.811 & 1.045 & 1.342 & 1.250 \\
\hline cost & pc2 & 0.809 & & & & & & \\
\hline & pc3 & 0.775 & & & & & & \\
\hline Relative & rela1 & 0.824 & 0.715 & 0.909 & 0.866 & 0.878 & 2.360 & 2.000 \\
\hline advantage & rela2 & 0.894 & & & & & & \\
\hline & rela3 & 0.897 & & & & & & \\
\hline & rela4 & 0.760 & & & & & & \\
\hline Trialability & tri1 & 0.862 & 0.795 & 0.921 & 0.871 & 0.874 & 1.445 & 1.430 \\
\hline & tri2 & 0.904 & & & & & & \\
\hline & tri3 & 0.909 & & & & & & \\
\hline Value & va1 & 0.900 & 0.845 & 0.943 & 0.908 & 0.909 & 2.054 & \\
\hline alignment & va2 & 0.932 & & & & & & \\
\hline & va3 & 0.926 & & & & & & \\
\hline
\end{tabular}

\subsection{Convergent validity}

Supporting Ringle et al. (2012), this study's result indicates that all factor loading values more than 0.70 (ranging from 0.760 to 0.953) exceed the suggested threshold value of 0.7 (Hair et al., 2016) and indicating convergence validity. Our research further tested convergent validity by assessing AVE, between 0.597 and 0.898, which exceeds the threshold value of 0.50 (Hair et al., 2010). Therefore, we can conclude that there was convergent validity of the scale.

\subsection{Reliability}

Reliability was tested by assessing Cronbach's alpha and composite reliability values. The Cronbach's alpha value ranged from 0.811 to 0.917 (see Table 1), and the value of composite reliability ranged from 0.879 to 0.941 , which is greater than the threshold value of 0.7 (Hair et al., 2016). Hence, it demonstrates a satisfactory level of reliability.

\subsection{Discriminant validity}

Heterotrait-monotrait ratio (HTMT) and Fornell-Larcker criterion were used to assess discriminant validity. According to the Fornell-Larcker approach (Fornell and Larcker, 1981), the square root of each construct's AVE value should be more than its highest correlation with any other construct of a model (Hair et al., 2016). As shown in Table 2, each construct's square root of AVE is more 
remarkable in the model than the correlation value. As the Fornell-Larcker criterion cannot reliably detect the lack of discriminant validity in common research situations (Henseler et al., 2015), the HTMT is also tested here. The HTMT value (see Table 3) of all the constructs was less than the conservative threshold value of 0.85, ensuring the discriminant validity (Henseler et al., 2015; Hair et al., 2016). Thus, discriminatory validity is not an issue for this study.

\subsection{Testing multicollinearity and coefficient of determination $\left(R^{2}\right)$}

As suggested by Kleinbaum et al. (1988), one effective technique, including the evaluation of variance inflation factor (VIF), was used to decide the presence of multicollinearity among independent variables in this research. The regression analysis outcome shows that the VIF ranges from 1.250 to 2.479, indicated in between 1 and 5 (Zuur et al., 2010) (see Table 3 and Figure 2). This concludes that multicollinearity is not the issue in this research.

Santosa et al. (2005) proposed a need to measure the model's explanatory powers by ascertaining the endogenous variable's coefficient of determination $\left(R^{2}\right)$. Since the $R^{2}$ value of this study's endogenous constructs is more significant than 0.26 , it indicates that the model has a strong explanatory power (Chin, 1998).

\section{Structural model analysis}

The hypotheses of this research and the structural model have been evaluated using path coefficient and effect size $\left(f^{2}\right)$ based on the recommendation of Hair et al. (2016). In this research, we used 5,000 bootstrap subsamples from 233 cases to analyze the findings' significance. A 5\%

\section{Table 2 Fornell-Larcker correlation matrix}

\begin{tabular}{|c|c|c|c|c|c|c|c|c|c|c|c|}
\hline & $B I$ & $C P$ & Comp & Compat & Custp & $E S$ & Obs & $P C$ & Rela & Tri & $V A$ \\
\hline $\mathrm{Bl}$ & 0.889 & & & & & & & & & & \\
\hline CP & 0.607 & 0.878 & & & & & & & & & \\
\hline Comp & 0.567 & 0.326 & 0.882 & & & & & & & & \\
\hline Compat & 0.645 & 0.433 & 0.410 & 0.875 & & & & & & & \\
\hline Custp & 0.767 & 0.496 & 0.477 & 0.589 & 0.918 & & & & & & \\
\hline ES & 0.453 & 0.370 & 0.221 & 0.396 & 0.448 & 0.925 & & & & & \\
\hline Obs & 0.707 & 0.445 & 0.301 & 0.549 & 0.635 & 0.335 & 0.926 & & & & \\
\hline PC & 0.193 & 0.265 & 0.128 & 0.265 & 0.247 & 0.303 & 0.227 & 0.843 & & & \\
\hline Rela & 0.699 & 0.463 & 0.485 & 0.532 & 0.611 & 0.474 & 0.569 & 0.311 & 0.846 & & \\
\hline Tri & 0.457 & 0.336 & 0.267 & 0.299 & 0.365 & 0.242 & 0.382 & 0.406 & 0.444 & 0.892 & \\
\hline VA & 0.630 & 0.431 & 0.435 & 0.542 & 0.584 & 0.436 & 0.465 & 0.380 & 0.612 & 0.373 & 0.919 \\
\hline
\end{tabular}

Note(s): $\mathrm{BI}=$ behavioral intention, $\mathrm{CP}=$ competitive pressure, CUST = customer pressure, $\mathrm{ES}=$ external support, $\mathrm{PC}=$ perceived cost, comp $=$ complexity, Compat $=$ compatibility, Tri $=$ trialability, Obs $=$ observability, Rela $=$ relative advantage, $\mathrm{VA}=$ value alignment

Table 3 HTMT approach and coefficient of determination

\begin{tabular}{|c|c|c|c|c|c|c|c|c|c|c|c|c|}
\hline & $B I$ & $C P$ & Comp & Compat & Custp & $E S$ & Obs & $P C$ & Rela & Tri & $V A$ & $\mathrm{R}^{2}$ \\
\hline $\mathrm{Bl}$ & - & & & & & & & & & & & 0.802 \\
\hline $\mathrm{CP}$ & 0.693 & - & & & & & & & & & & - \\
\hline Comp & 0.659 & 0.376 & - & & & & & & & & & - \\
\hline Compat & 0.751 & 0.503 & 0.479 & - & & & & & & & & - \\
\hline Custp & 0.867 & 0.550 & 0.540 & 0.672 & - & & & & & & & - \\
\hline ES & 0.533 & 0.425 & 0.258 & 0.468 & 0.512 & - & & & & & & - \\
\hline Obs & 0.792 & 0.493 & 0.338 & 0.621 & 0.698 & 0.379 & - & & & & & - \\
\hline PC & 0.181 & 0.282 & 0.144 & 0.287 & 0.255 & 0.306 & 0.202 & - & & & & - \\
\hline Rela & 0.799 & 0.523 & 0.558 & 0.616 & 0.683 & 0.560 & 0.630 & 0.315 & - & & & - \\
\hline Tri & 0.519 & 0.385 & 0.306 & 0.346 & 0.406 & 0.278 & 0.416 & 0.456 & 0.507 & - & & - \\
\hline VA & 0.709 & 0.481 & 0.494 & 0.618 & 0.644 & 0.500 & 0.506 & 0.398 & 0.686 & 0.417 & - & 0.486 \\
\hline
\end{tabular}


level of significance is considered in testing the structural model and projected hypotheses. The confidence interval report was further analyzed along with the $t$-values (1.96) and $p$-values (0.05) to examine the significance of the proposed hypothetical relationship.

As depicted in Table 4, nine hypotheses were supported at $5 \%$ significant level out of ten direct relationships projected. The outcomes showed that the perceived cost $(\beta=-0.147, t=4.050$, $p=0.00)$, relative advantages $(\beta=0.120, t=2.206, p=0.027)$, complexity $(\beta=0.161, t=3.229$, $p=0.001)$, compatibility $(\beta=0.104, t=2.489, p=0.013)$ and trialability $(\beta=0.105, t=2.931$, $p=0.003$ ) were connected positively with behavioral intention, supporting the hypotheses $\mathrm{H} 1, \mathrm{H} 2$, $\mathrm{H} 3, \mathrm{H} 4$ and $\mathrm{H} 5$. As suggested, observability $(\beta=0.236, t=4.141, p=0.00)$, competitor pressure $(\beta=0.173, t=4.625, p=0.000)$ and customer pressure $(\beta=0.237, t=3.640, p=0.000)$ are positively linked with the behavioral intention indicating $\mathrm{H} 6, \mathrm{H} 7$ and $\mathrm{H} 8$ are significant. $\mathrm{H} 9$ is rejected which anticipated the positive relationship of external support $(\beta=0.044, t=1.291, p=0.197$ ) with behavioral intention. However, the value alignment $(\beta=0.106, t=2.656, p=0.008$ ) is found to have positively related to the behavioral intention, supporting $\mathrm{H} 10$.

The $f^{2}$ is an additional tool of $R^{2}$ for analyzing the effect size test, which measures the effect of an independent variable on the dependent variable. Although $R^{2}$ is sensitive to the number of variables that is not an issue in this study, it used numerous variables to improve the robustness of the analysis. The $f^{2}$ values greater than 0 and $0.02,0.15$ and 0.35 denote a small, average or extensive exogenous effect on an endogenous variable accordingly (Cohen, 1988). This study concludes that the entire endogenous constructs have a small effect on behavioral intention (see Table 4).

\subsection{Testing the mediating effect of value alignment}

The bootstrapping method was used to analyze the mediation effect of value alignment on the relationship between relative advantages, complexity, compatibility, trialability, observability and perceived cost on behavioral intention based on suggestions of Hair et al. (2013) and Hayes and Preacher (2010). It is unnecessary to assume the products' sampling distributions or the indirect effect in the bootstrapping method (Hair et al., 2013; Hayes and Preacher, 2010). The mediating effect was tested with Smart-PLS 3.0 with 233 cases and 5,000 subsamples.

From the study results (Table 5), it is clear that value alignment mediates the association between relative advantages and behavioral intention $(\beta=0.034, t$-value $=2.399$, at $p<0.05)$, complexity and behavioral intention $(\beta=0.056, t$-value $=2.477$, at $p<0.05)$, compatibility and behavioral intention $(\beta=0.024, t$-value $=2.018$, at $p<0.05)$, as well as perceived cost and behavioral intention $(\beta=0.032$, $t$-value $=1.987$, at $p<0.05)$ supporting $\mathrm{H} 11, \mathrm{H} 12, \mathrm{H} 13$ and $\mathrm{H} 16$. The mediation effect is partial as direct $\left(\beta_{X Y}\right)$ and indirect relationships $\left(\left(\beta_{X M}\right)\right.$ and $\left.\left(\beta_{M Y}\right)\right)$ was found significantly with the inclusion of mediator in all cases. However, trialability $(\beta=0.003$,

\begin{tabular}{|c|c|c|c|c|c|c|c|c|}
\hline Hypothesis & $\begin{array}{l}\text { STD } \\
\text { beta }\end{array}$ & $\begin{array}{l}\text { STD } \\
\text { error }\end{array}$ & $\mathrm{t}$-values & $p$-values & $2.5 \%$ & $97.5 \%$ & $\begin{array}{l}\text { Significance } \\
(\mathrm{p}<0.05)\end{array}$ & $f^{2}$ \\
\hline $\mathrm{H} 1: \mathrm{COST} \rightarrow \mathrm{Bl}$ & 0.147 & 0.036 & 4.050 & 0.000 & -0.217 & -0.075 & Supported & 0.081 \\
\hline $\mathrm{H} 2:$ RELA $\rightarrow \mathrm{Bl}$ & 0.120 & 0.054 & 2.206 & 0.027 & 0.021 & 0.231 & Supported & 0.031 \\
\hline H3: COMPEX $\rightarrow \mathrm{Bl}$ & -0.161 & 0.050 & 3.229 & 0.001 & 0.067 & 0.262 & Supported & 0.088 \\
\hline $\mathrm{H} 4: \mathrm{COMPAT} \rightarrow \mathrm{BI}$ & 0.104 & 0.042 & 2.489 & 0.013 & 0.017 & 0.182 & Supported & 0.029 \\
\hline $\mathrm{H} 5: \mathrm{TRI} \rightarrow \mathrm{Bl}$ & 0.105 & 0.036 & 2.931 & 0.003 & 0.032 & 0.173 & Supported & 0.038 \\
\hline $\mathrm{H} 6: \mathrm{OBS} \rightarrow \mathrm{Bl}$ & 0.236 & 0.057 & 4.141 & 0.000 & 0.134 & 0.358 & Supported & 0.139 \\
\hline $\mathrm{H} 7: \mathrm{CP} \rightarrow \mathrm{Bl}$ & 0.173 & 0.037 & 4.625 & 0.000 & 0.098 & 0.246 & Supported & 0.100 \\
\hline $\mathrm{H} 8: \mathrm{CUST} \rightarrow \mathrm{E}$ & 0.237 & 0.065 & 3.640 & 0.000 & 0.105 & 0.357 & Supported & 0.114 \\
\hline $\mathrm{H9}: \mathrm{ES} \rightarrow \mathrm{Bl}$ & 0.044 & 0.034 & 1.291 & 0.197 & -0.024 & 0.111 & NS & 0.007 \\
\hline $\mathrm{H} 10: \mathrm{VA} \rightarrow \mathrm{Bl}$ & 0.106 & 0.040 & 2.656 & 0.008 & 0.027 & 0.182 & Supported & 0.028 \\
\hline
\end{tabular}

Note(s): $\mathrm{BI}=$ behavioral intention, $\mathrm{CP}=$ competitive pressure, $\mathrm{CUST}=$ customer pressure, $\mathrm{ES}=$ external support, $\mathrm{PC}=$ perceived cost, Compex $=$ complexity, Compat $=$ compatibility, Tri $=$ trialability,

Obs $=$ observability, Rela $=$ relative advantage,$V A=$ value alignment 
Table 5 Mediating effect of value alignment

\begin{tabular}{llccccl} 
Hypotheses & Relationships & Beta & Standard error & t-value & p-value & Decision \\
\hline $\mathrm{H} 11$ & RELA $\rightarrow \mathrm{VA} \rightarrow \mathrm{BI}$ & 0.034 & 0.014 & 2.399 & 0.018 & Partial mediation \\
$\mathrm{H} 12$ & COMPEX $\rightarrow \mathrm{VA} \rightarrow \mathrm{BI}$ & 0.056 & 0.018 & 2.477 & 0.015 & Partial mediation \\
$\mathrm{H} 13$ & COMPAT $\rightarrow \mathrm{VA} \rightarrow \mathrm{BI}$ & 0.024 & 0.012 & 2.018 & 0.044 & Partial mediation \\
$\mathrm{H} 14$ & $\mathrm{TRI} \rightarrow \mathrm{VA} \rightarrow \mathrm{BI}$ & 0.003 & 0.007 & 0.448 & 0.654 & No mediation \\
$\mathrm{H} 15$ & $\mathrm{OBS} \rightarrow \mathrm{VA} \rightarrow \mathrm{BI}$ & 0.007 & 0.008 & 0.844 & 0.399 & No mediation \\
$\mathrm{H} 16$ & COST $\rightarrow \mathrm{VA} \rightarrow \mathrm{BI}$ & 0.032 & 0.011 & 1.987 & 0.041 & Partial mediation
\end{tabular}

$t$-value $=0.448$, at $p=0.654>0.05)$ and observability $(\beta=0.056, t$-value $=2.477$, at $p=0.399>0.05)$ do not mediate the association between value alignment and behavioral intention. Therefore, we reject $\mathrm{H} 14$ and $\mathrm{H} 15$.

\section{Discussion}

The study used a holistic research model, affecting entrepreneurs' value alignment and adoption intention, developed based on Rogers' DOI theory and TOE model and later tested the model empirically with $\mathrm{H} 16$ with six suggested mediating relationships. The study's findings suggest that the two-factor theory in examining the technological and environmental factors predicts better understanding of AR adoption intention in Malaysia's tourism business. All the factors (except fourth) are confirmed and offered the necessary support exhibited in Figure 2. The DOI and TOE constructs were found statistically significant and appeared with a strong resemblance in the comprehensive model. The study also offers informative details outlined below based on the research framework.

First, a significant association was found in this research between customer pressure and behavioral intention. Competitor pressure is another critical predictor affecting AR adoption intention among retailers in Malaysia, consistent with the previous studies (Wanyoike et al., 2012; El-Gohary, 2012) conducted on SMEs in tourism. Thus, the higher the possibility of adopting AR by competitors, the higher the SMEs' propensity to accept it as far as their existence is concerned. The other environmental factor, external support, is surprisingly found insignificant regarding the relationship to behavioral intention to use AR. That is because travel agencies in Malaysia are not receiving products from one supplier, and not all suppliers accept technology into their business. The other possible reason may be that Malaysia's government has not yet established an institution supporting this technology implementation in businesses. This study's result is inconsistent with that of previous studies done by Wanyoike et al. (2012), El-Gohary (2012) and Matikiti et al. (2018).

Second, this study's results confirmed that perceived cost has a significant negative effect on behavioral intention. This result aligns with the previous research on virtual reality technology (Jang and Park, 2019; Yang and Lee, 2019). System development for providing AR facilities needed some infrastructure and systems, which incur extra costs for the retailers. Similarly, observability is the extent to which the innovation is visible and has a maximum effect on behavioral intention among the other variables' minor effects. Our findings suggest that complexity has a negative effect on the behavioral intention concerning the innovation factors. The results align with the earlier observations on innovation literature (Kleijnen et al., 2009).

Third, the current findings have shown that relative advantages are a significant determinant of the intent to embrace AR, consistent with earlier research (Amaro and Duarte, 2015; Lu et al., 2011). On the contrary, complexity is the hindrances, which impede the adoption decision complied with the previous research on information systems (Phipps et al., 2013). Fourth, this research found a significant positive relationship between AR's compatibility and behavioral intention compatible with the prior research (Lee et al., 2011; Pham and Ho, 2015). This indicates that the higher the AR product to users, the higher will be the behavioral intention. Similarly, Innovation trialability allows users to feel comfortable and gain confidence over it. The present study follows the past study of Wang (2014) and implies that allowing trialability of augment realities, technology will allow Malaysians to enhance their willingness. 
Fifth, the current research has found that value alignment is a significant determinant of the decision to follow AR. The outcome shows that retail stores' adoption intent is motivated by an alignment of value with increased truth, as created by a perception of AR properties. The analysis results reflect previous research, suggesting that perceived value for new ICT adoption is a significant predictor (Chen et al., 2018). It demonstrates the critical role of the value alignment in AR acceptance for the ultimate experience. Finally, according to the result, value alignment mediates partially between technological factors (relative advantages and behavioral intention, complexity and behavioral intention, compatibility) and behavioral intent except for trialability and observability in the Malaysian tours and travel sectors. These results support Yang and Lee's (2019) empirical findings in the Chinese crowdfunding context.

\section{Theoretical implications}

This research's theoretical contribution to academia is threefold: a new context, a new model and new findings. It contributes to the tourism and hospitality management literature by exploring relevant factors that affect AR technology adoption in SMEs.

Concerning the new context, research in the augmented reality (AR) from the travel and tourism perspective is limited for a comprehensive understanding. First, prior research on AR adoption has looked at it from the standpoint of consumers, ignoring organizational outlook. The current study emphasizes the importance of studying technology adoption from an organizational standpoint. Future research could look into the organizational context of new technology acceptance and adoption. The research adds to information system insights by understanding how this novel technology is accepted and adopted within organizations. Second, this study caters to the perspective of Malaysia, which could be the foundation stone for similar developing country's research to follow the factor to enhance the diffusion of this technology rapidly. Third, this model was tested in the travel agency's acceptance of AR, which can be applied to other new IT adoption contexts, such as the adoption intention of artificial intelligence. Researchers can extend or replicate in the future as this research has its measurement scales validated by PLS statistical analysis.

As for a new model, the present study offered a comprehensive model combining the TOE and DOI models, rare in this sector. This study relies on the TOE framework to emphasize the technology and organizational perspective simultaneously. It also integrates the DOI model constructs like relative advantages, compatibility, complexity, trialability and observability as technology-specific factors that may affect AR adoption. In addition, perceived cost is also borrowed from the literature as technological characteristics. External support is proposed to include the functional perspective and organizational capabilities. Inspired by Wanyoike et al. (2012), this study proposes customer and competitor pressures that influence the adoption of AR technology in tourism sectors.

Regarding the new findings, this study brought value alignment construct (VA) in the model, and thus it fulfills the literature gap by empirically establishing it as a mediation construct. The study also compares these findings to the previous AR technology adoption factors and shows how these findings differ and are differently interpreted from past research. Like previous study this study confirmed that external support was insignificant. It is indicates the newness of this study. Likewise, VA did not mediate between trialability and observability, thus future studies can test further in similar situations.

\section{Practical implications}

The outcomes of the analysis provide essential management lessons that can support administrators and policymakers in various ways. First, the practitioners could realize the role of value alignment in mediating behavioral intention with other factors. Buying AR technology is not just watching advertisements and then going to collect it. The entrepreneurs will buy or use when they feel those products enhance the firm's value by adoption. However, AR suppliers' managers can inform the specific experience articulated in the latest technology, describing the level of consumer value proposition given. That will enable us to interact explicitly and match the technology to their specific needs.

PAGE 12 JOURNAL OF TOURISM FUTURES $\mid$ VOL. $\mathbf{m}$ NO. $\mathbf{m}$ 
Second, external support did not function as expected in the proposed model. Since this could be due to the unavailability of supporting institutions for implementing the latest technology in businesses, the Malaysian government and its responsible body should care for this missing aspect to materialize the upcoming Fourth Industrial Revolution. We also suggest a future study to understand why this feature, which is usually necessary to introduce innovation, is unsuitable for AR adoption. However, the supplies should also set up various customer service centers nearby for a stain-free AR experience.

Third, this study's results indicate that operating costs and complexity are key factors that influence entrepreneurs' value alignment in line with AR acceptance. Concerning overhead expenses, administrators are also advised to introduce incentives to minimize escalated service charges or offer service bundles to get aspiring entrepreneurs. Managers should suggest, for example, delivering various packages of after-sales services and free installation charges.

Fourth, the paper stresses the promise of AR and the role of senior management in putting it into practice. If the organization's top management is committed and concentrated on using technology and has clarity on value formation and new implementation methods, adoption will be more receptive, and outcomes will be achieved.

Fifth, competitive pressure and customer pressure are two external pressures that have been found to have a notable impact on behavioral intent. Managers and owners ought to have a procedure in place (opinion pool, feedback solicitation, reaction testing) to understand client expectations regarding products and their delivery. It will assist them in customer acquisition as well as keeping existing ones informed. They should also constantly reassess their competitive advantages and make immediate improvements.

Besides, the present paper also contributes to the future of tourism. This paper will guide managers and policymakers in the tourism sector to see the factors required to bring AR technology in this sector, shaping the future of tourism. Likewise, since AR will turn around the future of the travel and tourism industry with improved technologies, the demand for up-to-date AR technology will be high in the future. This paper indicates that the customer pressure and competitive pressure toward up-to-date technology are pertinent to the future survival in the tourism industry, and this will provide essence to be well informed about the changing technology and their adoption.

\section{Conclusion, limitation and recommendation for future research}

The outcomes showed that the perceived cost, relative advantages, complexity and compatibility, observability, competitor pressure, value alignment, customer pressure and trialability are positively connected with the behavioral intention, while external support is not related to behavioral intention. In addition, value alignment partially mediates the association between relative advantages and behavioral intention, complexity and behavioral intention, compatibility, behavioral intention, as well as perceived cost and behavioral intention except for trialability and observability.

While the current research gives pragmatic as well as theoretical contributions, there are drawbacks. The study has limitations. It does not include the social norm construct because this is not an individual behavior. However, peer influence and celebrity endorsement have an enormous effect on the usage decision for any technology. Through using celebrities and peers in product demos and commercials, advertisers can demonstrate the innovation, interactivity and vividness of AR applications as a core value proposition. Therefore, we suggest including social norms in future studies. In addition, like all cross-sectional analyses, this study offers a precise glimpse during the survey. Given the rapid technical progress, this study's results need to be revisited as technology progresses. More specifically, studies may be performed in an experimental design laboratory environment in which researchers observe AR technologies first-hand. An experimental test design will give researchers more insight into the particular AR attributes affecting brand interaction. 


\section{References}

Al-Jabri, I.M. and Sohail, M.S. (2012), "Mobile banking adoption: application of diffusion of innovation theory", Journal of Electronic Commerce Research, Vol. 13 No. 4, pp. 379-391.

Al-Zoubi, M.I. (2013), "Predicting e-business adoption through integrating the constructs of the Rogers's diffusion of innovation theory combined with technology-organization-environment model", International Journal of Advanced Computer Research, Vols 394-13, pp. 63-73.

Agarwal, R. and Prasad, J. (1997), "The role of innovation characteristics and perceived voluntariness in the acceptance of information technologies", Decision Sciences, Vol. 28 No. 3, pp. 557-582.

Alam, S.S., Ali, M.Y. and Jani, M.F.M. (2011), "An empirical study of factors affecting electronic commerce adoption among SMEs in Malaysia", Journal of Business Economics and Management, Vol. 12 No. 2, pp. 375-399.

Alam, S.S., Omar, N.A., Ariffin, A.A.M. and Hashim, N.M.H.N. (2018), "Integrating TPB, TAM, and DOI theories: an empirical evidence for the adoption of mobile banking among customers in Klang Valley, Malaysia", International Journal of Business and Management Science, Vol. 8 No. 2, pp. 385-403.

Alam, S.S. and Sayuti, N.M. (2011), "Applying the theory of planned behavior (TPB) in halal food purchasing", International Journal of Commerce and Management, Vol. 21 No. 1, pp. 8-20.

Alshamaila, Y., Papagiannidis, S. and Li, F. (2013), "Cloud computing adoption by SMEs in the northeast of England: a multi-perspective framework", Journal of Enterprise Information Management, Vol. 26 No. 3, pp. 250-275.

Amaro, S. and Duarte, P. (2015), "An integrative model of consumers' intentions to purchase travel online", Tourism Management, Vol. 46, pp. 64-79.

Calisir, F., Gumussoy, C.A., Bayraktaroglu, A.E. and Karaali, D. (2014), "Predicting the intention to use a web-based learning system: perceived content quality, anxiety, perceived system quality, image, and the technology acceptance model", Human Factors and Ergonomics in Manufacturing and Service Industries, Vol. 24 No. 5, pp. 515-531.

Chandra, S. and Kumar, K.N. (2018), "Exploring factors influencing organizational adoption of augmented reality in e-commerce: empirical analysis using technology-organization-environment model", Journal of Electronic Commerce Research, Vol. 19 No. 3, pp. 237-265.

Chang, B.Y., Magobe, M.J. and Kim, Y.B. (2015), "E-commerce applications in the tourism industry: a Tanzania case study", South African Journal of Business Management, Vol. 46 No. 4, pp. 53-64.

Chen, M., Saad, W. and Yin, C. (2018), "Virtual reality over wireless networks: quality-of-service model and learning-based resource management”, IEEE Transactions on Communications, Vol. 66, pp. 5621-5635.

Chin, W.W. (1998), "The partial least squares approach for structural equation modeling", in Marcoulides, G.A. (Ed.), Modern Methods for Business Research, Lawrence Erlbaum Associates, Mahwah, New Jersey, pp. 295-358.

Chiu, C.Y., Chen, S. and Chen, C.L. (2017), "An integrated perspective of TOE framework and innovation diffusion in broadband mobile applications adoption by enterprises", International Journal of Management, Economics and Social Sciences (IJMESS), Vol. 6 No. 1, pp. 14-39.

Cohen, J. (1988), Statistical Power Analysis for the Behavioral Sciences, Lawrence Erlbaum, Mahwah, New Jersey.

Cranmer, E., Jung, T., tom Dieck, M.C. and Miller, A. (2016), Implementing Augmented Reality to Increase Tourist Attraction Sustainability, Dublin, ARVR Innovate, 27 April 2016.

Cranmer, E.E., tom Dieck, M.C. and Fountoulaki, P. (2020), "Exploring the value of augmented reality for tourism", Tourism Management Perspectives, Vol. 35, 100672.

Cranmer, E.E., tom Dieck, M.C. and Jung, T. (2018), "How can tourist attractions profit from augmented reality?", in Jung, T. and tom Dieck, M.C. (Eds), Augmented Reality and Virtual Reality, Springer, Cham, pp. 21-32.

Dibra, M. (2015), "Rogers theory on diffusion of innovation-the most appropriate theoretical model in the study of factors influencing the integration of sustainability in tourism businesses", Procedia-Social and Behavioral Sciences, Vol. 195, pp. 1453-1462.

Do, H.N., Shih, W. and Ha, Q.A. (2020), "Effects of mobile augmented reality apps on impulse buying behavior: an investigation in the tourism field", Heliyon, Vol. 6 No. 8, e04667. 
El-Gohary, H. (2012), "Factors affecting e-marketing adoption and implementation in tourism firms: an empirical investigation of Egyptian small tourism organisations", Tourism Management, Vol. 33 No. 5, pp. 1256-1269, doi: 10.1016/j.tourman.2011.10.013.

Fornell, C. and Larcker, D.F. (1981), "Evaluating structural equation models with unobservable variables and measurement error”, Journal of Marketing Research, Vol. 18 No. 1, p. 39, doi: 10.2307/3151312.

Gangwar, H., Date, H. and Raoot, A.D. (2014), "Review on IT adoption: insights from recent technologies", Journal of Enterprise Information Management, Vol. 27 No. 4, pp. 488-502.

Hair, J.F., Black, W.C. and Babin, B.J. (2010), Multivariate Data Analysis, Prentice-Hall, p. 816.

Hair, J.F., Jr, Hult, G.T.M., Ringle, C. and Sarstedt, M. (2013), A Primer on Partial Least Squares Structural Equation Modeling (PLS-SEM), Sage Publications.

Hair, J.F., Jr., Hult, G.T.M., Ringle, C.M. and Sarstedt, M. (2016), A Primer on Partial Least Squares Structural Equation Modeling (PLS-SEM), 2nd ed., Sage Publications, Thousand Oaks.

Harman, H.H. (1976), Modern Factor Analysis, University of Chicago Press.

Hassan, A. and Rahimi, R. (2016), "Consuming 'innovation' in tourism: augmented reality as an innovation tool in digital tourism marketing", in Pappas, N. and Bregoli, I. (Eds), Global Dynamics in Travel, Tourism, and Hospitality, IGI Global, pp. 130-147.

Hayes, A.F. and Preacher, K.J. (2010), "Quantifying and testing indirect effects in simple mediation models when the constituent paths are nonlinear", Multivariate Behavioral Research, Vol. 45 No. 4, pp. 627-660.

Hayes, T.P., Jr (2012), "Predicting information technology adoption in small businesses: an extension of the technology acceptance model", Academy of Information and Management Sciences Journal, Vol. 15 No. 1, pp. 37-46.

$\mathrm{He}, \mathrm{Z}$., Wu, L. and Li, X. (2018), "When are meets tech: the role of augmented reality in enhancing museum experiences and purchase intentions", Tourism Management, Vol. 68, pp. 127-139.

Henseler, J., Ringle, C.M. and Sarstedt, M. (2015), "A new criterion for assessing discriminant validity in variance-based structural equation modeling", Journal of the Academy of Marketing Science, Vol. 43 No. 1, pp. 115-135.

Huang, T.L. and Liao, S. (2015), "A model of acceptance of augmented-reality interactive technology: the moderating role of cognitive innovativeness", Electronic Commerce Research, Vol. 15 No. 2, pp. 269-295.

Hwang, B.N., Huang, C.Y. and Wu, C.H. (2015), "A TOE approach to establish a green supply chain adoption decision model in the semiconductor industry", Sustainability, Vol. 8 No. 168, pp. 1-30.

Jang, Y. and Park, E. (2019), "An adoption model for virtual reality games: the roles of presence and enjoyment”, Telematics and Informatics, Vol. 42, 101239.

Jung, T., Lee, H., Chung, N. and tom Dieck, M.C. (2018), "Cross-cultural differences in adopting mobile augmented reality at cultural heritage tourism sites", International Journal of Contemporary Hospitality Management, Vol. 30 No. 3, pp. 1621-1645.

Karahanna, E., Agarwal, R. and Angst, C.M. (2006), "Reconceptualizing compatibility beliefs in technology acceptance research", MIS Quarterly, Vol. 30 No. 4, pp. 781-804.

Karahanna, E., Straub, D.W. and Chervany, N.L. (1999), "Information technology adoption across time: a cross-sectional comparison of pre-adoption and post-adoption beliefs", MIS Q, Vol. 23, pp. 183-213.

Kleijnen, M., Lee, N. and Wetzels, M. (2009), "An exploration of consumer resistance to innovation and its antecedents", Journal of Economic Psychology, Vol. 30 No. 3, pp. 344-357.

Kleinbaum, D.G., Kupper, L.L. and Muller, K.E. (1988), Applied Regression Analysis and Other Multivariable Methods, Duxbury Press, Belmont, California.

Kolodinsky, J.M., Hogarth, J.M. and Hilgert, M.A. (2004), "The adoption of electronic banking technologies by US consumers", The International Journal of Bank Marketing, Vol. 22 No. 45, pp. 238-259.

Kourouthanassis, P., Boletsis, C., Bardaki, C. and Chasanidou, D. (2015), "Tourists responses to mobile augmented reality travel guides: the role of emotions on adoption behavior", Pervasive and Mobile Computing, Vol. 18, pp. 71-87.

Lazim, N.A.M. and Rahman, K.A.A.A. (2015), "State-of-the-art responses on augmented reality application in Malaysia", International Journal on Sustainable Tropical Design Research and Practice, Vol. 8, pp. 28-34. 
Lee, J., Kim, J. and Choi, J.Y. (2019), "The adoption of virtual reality devices: the technology acceptance model integrating enjoyment, social interaction, and strength of the social ties", Telematics and Informatics, Vol. 39, pp. 37-48.

Lee, Y.H., Hsieh, Y.C. and Hsu, C.N. (2011), "Adding innovation diffusion theory to the technology acceptance model: supporting employees' intentions to use e-learning systems", Educational Technology and Society, Vol. 14 No. 4, pp. 124-137.

Li, H., Gupta, A., Zhang, J. and Flor, N. (2020), "Who will use augmented reality? An integrated approach based on text analytics and field survey", European Journal of Operational Research, Vol. 281 No. 3, pp. 502-516.

Lin, C.Y. and Ho, Y.H. (2010), "The influence of environmental uncertainty on corporate green behavior: an empirical study with small and medium-size enterprises", Social Behavior and Personality: An International Journal, Vol. 38 No. 5, pp. 691-696.

Lin, S. (2016), "Identifying the critical success factors and an optimal solution for mobile technology adoption in travel agencies", International Journal of Tourism Research, Vol. 19 No. 2, pp. 127-144.

Liu, Z., Min, Q. and Ji, S. (2008), "A comprehensive review of research in IT adoption, wireless communications, networking, and mobile computing", WiCOM '08. 4th International Conference, 12-14 October, School of Management, Dalian University of Technology, Dalian, pp. 1-5.

Lou, L., Tian, Z. and Koh, J. (2017), "Tourist satisfaction enhancement using mobile QR code payment: an empirical investigation", Sustainability, Vol. 9 No. 1186, pp. 1-14.

Lowry, P.B. and Gaskin, J. (2014), "Partial least squares (PLS) structural equation modeling (SEM) for building and testing behavioral causal theory: when to choose it and how to use it", IEEE Transactions on Professional Communication, Vol. 57 No. 2, pp. 123-146.

Lu, Y., Cao, Y., Wang, B. and Yang, S. (2011), "A study on factors that affect users' behavioral intention to transfer usage from the offline to the online channel", Computers in Human Behavior, Vol. 27 No. 1, pp. 355-364.

Luarn, P. and Lin, H.H. (2005), "Toward an understanding of the behavioral intention to use mobile banking", Computers I Human Behavior, Vol. 21, pp. 873-891.

Matikiti, R., Mpinganjira, M. and Roberts-Lombard, M. (2018), "Application of the technology acceptance model and the technology-organisation-environment model to examine social media marketing use in the South African tourism industry", South African Journal of Information Management, Vol. 20 No. 1, pp. 1-12, a790, doi: 10.4102/sajim.v20i1.790.

McLean, G. and Wilson, A. (2019), "Shopping in the digital world: examining customer engagement through augmented reality mobile applications", Computers in Human Behavior, Vol. 101, pp. 210-224.

Min, J. and Kim, B. (2015), "How are people enticed to disclose personal information despite privacy concerns in social network sites? The calculus between benefit and cost", Journal of the Association for Information Science and Technology, Vol. 66 No. 4, pp. 839-857.

Moghavvemi, S., Mohd Salleh, N.A., Zhao, W. and Mattila, M.M. (2012), "The entrepreneur's perception of information technology adoption: an empirical analysis of the role of precipitating events on usage behavior", Innovation: Management, Policy and Practice, Vol. 14 No. 3, pp. 220-235.

Moore, G.C. and Benbasat, I. (1991), "Development of an instrument to measure the perceptions of adopting an information technology innovation", Information Systems Research, Vol. 2 No. 3, pp. 192-221.

Ng, C.C. and Ramasamy, C. (2018), "Augmented reality marketing in Malaysia - future scenarios", Social Sciences, Vol. 7 No. 224, pp. 1-15.

Oliveira, T. and Martins, M.F. (2011), "Literature review of information technology adoption models at firm level”, Electronic Journal of Information Systems Evaluation, Vol. 14 No. 1, pp. 110-121.

Olsson, T., Lagerstam, E., Kärkkäinen, T. and Väänänen-Vainio-Mattila, K. (2013), "Expected user experience of mobile augmented reality services: a user study in the context of shopping centres", Personal and Ubiquitous Computing, Vol. 17 No. 2, pp. 287-304.

Paydar, S., Endut, I.R., Yahya, S. and Rahman, S.H.A. (2014), "Environmental factors influencing the intention to adopt RFID technology in retail industry: an empirical study", Asia-Pacific Journal of Management Research and Innovation, Vol. 10 No. 1, pp. 13-26.

Pham, T.T.T. and Ho, J.C. (2015), "The effects of product-related, personal related factors and attractiveness of alternatives on consumer adoption of NFC-based mobile payments", Technology in Society, Vol. 43, pp. 159-172. 
Phipps, M., Ozanne, L.K., Luchs, M.G., Subrahmanyan, S., Kapitan, S., Catlin, J.R. and Weaver, T. (2013), "Understanding the inherent complexity of sustainable consumption: a social cognitive framework", Journal of Business Research, Vol. 66 No. 8, pp. 1227-1234.

Piaralal, S.K., Nair, S.R., Yahya, N. and Karim, J.A. (2015), "An integrated model of the likelihood and extent of adoption of green practices in small and medium sized logistics firms", American Journal of Economics, Vol. 5 No. 2, pp. 251-258.

Plsek, P. and Greenhalgh, T. (2001), "The challenge of complexity in health care", Complexity Science, Vol. 323, pp. 625-628.

Podsakoff, P.M., MacKenzie, S.B., Lee, J.Y. and Podsakoff, N.P. (2003), "Common method biases in behavioral research: a critical review of the literature and recommended remedies", Journal of Applied Psychology, Vol. 88 No. 5, pp. 879-903, doi: 10.1037/0021-9010.88.5.879.

Quinting, A., Lins, S., Szefer, J. and Sunyaev, A. (2017), "Advancing the adoption of a new generation of certifications - a theoretical model to explain the adoption of continuous cloud service certification by certification authorities", in Leimeister, J.M. and Brenner, W. (Eds), Proceedings der 13. Internationalen Tagung Wirtschaftsinformatik (WI 2017), St. Gallen, S, pp. 1465-1476.

Racherla, P. and Hu, C. (2008), "eCRM system adoption by hospitality organisations: a technology-organisationenvironment (TOE) framework”, Journal of Hospitality and Leisure Marketing, Vol. 17 Nos 1-2, pp. 30-58.

Ramdani, B., Lorenzo, O. and Kawalek, P. (2009), "Information systems innovations adoption and diffusion among SMEs: current status and future prospects", International Journal of E-Adoption (IJEA), Vol. 1 No. 1 , pp. 33-45.

Rauschnabel, P.A., Rossmann, A. and tom Dieck, M.C. (2017), "An adoption framework for mobile augmented reality games: the case of Pokémon Go", Computers in Human Behavior, Vol. 76, pp. 276-286.

Richman, W.L., Kiesler, S., Weisband, S. and Drasgow, F. (1999), "A meta-analytic study of social desirability distortion in computer-administered questionnaires, traditional questionnaires, and interview", Journal of Applied Psychology, Vol. 84, pp. 754-775, doi: 10.1037/0021-9010.84.5.754.

Ringle, C., Wende, S. and Will, A. (2005), SmartPLS 2.0 (Beta), Hamburg, available at: www.smartpls.de.

Ringle, C.M. and Sarstedt, M. (2016), "Gain more insight from your PLS-SEM results: the importanceperformance map analysis", Industrial Management and Data Systems, Vol. 116 No. 9, pp. 1865-1886.

Ringle, C.M., Sarstedt, M. and Mooi, E.A. (2010), "Response-based segmentation using finite mixture partial least squares: theoretical foundations and an application to American customer satisfaction index data", Annals of Information System, Vol. 36 No. 1, doi: 10.1007/978-1-4419-1280-02.

Ringle, C.M., Sarstedt, M. and Straub, D. (2012), "A critical look at the use of PLS-SEM in MIS quarterly", MIS Quarterly (MISQ), Vol. 36 No. 1, pp. iii-xiv.

Rogers, E.M. (1962), Diffusion of Innovations, Free Press of Glencoe, New York, NY.

Rogers, E.M. (1995), "Diffusion of innovations: modifications of a model for telecommunications", in Die diffusion von innovationen in der telekommunikation, Springer, Berlin and Heidelberg, pp. 25-38.

Rogers, E.M. (2003), Diffusion of Innovations, Simon and Shuster, New York.

Santosa, P.I., Wei, K.K. and Chan, H.C. (2005), "User involvement and user satisfaction with informationseeking activity", European Journal of Information Systems, Vol. 14 No. 4, pp. 361-370.

Selamat, Z., Jaffar, N. and Ong, B.H. (2009), "Technology acceptance in Malaysian banking industry", European Journal of Economics, Finance and Administrative Sciences, Vol. 1 No. 17, pp. 143-155.

Shin, D. (2019), "How does immersion work in augmented reality games? A user-centric view of immersion and engagement", Information, Communication and Society, Vol. 22 No. 9, pp. 1212-1229.

Thong, J.Y. (1999), "An integrated model of information systems adoption in small businesses", Journal of Management Information Systems, Vol. 15 No. 4, pp. 187-214.

tom Dieck, M.C. and Jung, T. (2017), "Value of augmented reality at cultural heritage sites: a stakeholder approach", Journal of Destination Marketing and Management, Vol. 6 No. 2, pp. 110-117.

tom Dieck, M.C., Jung, T. and Han, D.I. (2016), "Mapping requirements for the wearable smart glasses augmented reality museum application", Journal of Hospitality and Tourism Technology, Vol. 7 No. 3, pp. 230-253.

Tussyadiah, I., Jung, T. and tom Dieck, M.C. (2018), "Embodiment of wearable augmented reality technology in tourism experiences", Journal of Travel Research, Vol. 57 No. 5, pp. 597-611. 
Ukpabi, D.C. and Karjaluoto, H. (2016), "Consumers' acceptance of information and communications technology in tourism: a review", Telematics and Informatics, Vol. 34 No. 5, pp. 618-644.

Ungan, M. (2005), "Management support for the adoption of manufacturing best practices: key factors", International Journal of Production Research, Vol. 43 No. 18, pp. 3803-3820.

Van den Berg, J. and van der Lingen, E. (2019), "An empirical study of the factors affecting the adoption of mobile enterprise applications", South African Journal of Industrial Engineering, Vol. 30 No. 1, pp. 124-146.

Wang, E.S.T. (2014), "Perceived control and gender difference on the relationship between trialability and intent to play new online games", Computers in Human Behavior, Vol. 30, pp. 315-320.

Wang, Y.S., Li, H.T., Li, C.R. and Zhang, D.Z. (2016), “Factors affecting hotels' adoption of mobile reservation systems: a technology-organization-environment framework”, Tourism Management, Vol. 53, pp. 163-172.

Wanyoike, D.M., Mukulu, E. and Waititu, A.G. (2012), "ICT attributes as determinants of E-commerce adoption by formal small enterprises in urban Kenya", International Journal of Business and Social Science, Vol. 3 No. 23, pp. 65-74

Weng, H.H.R., Chen, J.S. and Chen, P.C. (2015), "Effects of green innovation on environmental and corporate performance: a stakeholder perspective", Sustainability, Vol. 7, pp. 4997-5027.

Wu, X. and Subramaniam, C. (2009), New understanding of RFID adoption and infusion in retail supply chain, Paper presented in System Sciences, 2009. HICSS'09. 42nd Hawaii International Conference, IEEE, Washington, District of Columbia, pp. 1-10.

Yang, Q. and Lee, Y.C. (2019), "An investigation of enablers and inhibitors of crowdfunding adoption: empirical evidence from startups in China", Human Factors and Ergonomics in Manufacturing and Service Industries, Vol. 29 No. 1, pp. 5-21.

Zhang, H., He, J., Shi, X., Hong, Q., Bao, J. and Xue, S. (2020), "Technology characteristics, stakeholder pressure, social influence, and green innovation: empirical evidence from Chinese express companies", Sustainability, Vol. 12 No. 2891, pp. 1-19, doi: 10.3390/su12072891.

Yung, R. and Khoo-Lattimore, C. (2017), "New realities: a systematic literature review on virtual reality and augmented reality in tourism research", Current Issues in Tourism, Vol. 22 No. 1, pp. 1-26.

Zhang, K.Z.K., Benyoucef, M. and Zhao, S.J. (2016), "Building brand loyalty in social commerce: the case of brand microblogs", Electronic Commerce Research and Applications, Vol. 15, pp. 14-25.

Zulkifli, A.N., Alnagrat, A., Jamah, A. and Che Mat, R. (2016), "Development and evaluation of i-brochure: a mobile augmented reality application", Journal of Telecommunication, Electronic and Computer Engineering, Vol. 8 No. 10 , pp. $145-150$.

Zuur, A.F., leno, E.N. and Elphick, C.S. (2010), "A protocol for data exploration to avoid common statistical problems", Methods in Ecology and Evolution, Vol. 1 No. 1, pp. 3-14.

\section{Further reading}

Davis, F.D. (1986), "Technology acceptance model for empirically testing new end-user information systems theory and results", Unpublished doctoral dissertation, MIT.

Rauschnabel, P.A., He, J. and Ro, Y.K. (2018), "Antecedents to the adoption of augmented reality smart glasses: a closer look at privacy risks", Journal of Business Research, Vol. 92, pp. 374-384.

Watson, J., Ghosh, A.P. and Trusov, M. (2018), "Swayed by the numbers: the consequences of displaying product review attributes", Journal of Marketing, Vol. 82 No. 6, pp. 109-131.

Yang, S., Carlson, J.R. and Chen, S. (2020), "How augmented reality affects advertising effectiveness: the mediating effects of curiosity and attention toward the ad", Journal of Retailing and Consumer Services, Vol. 54, 102020

Yim, M.Y.C., Chu, S.C. and Sauer, P.L. (2017), "Is augmented reality technology an effective tool for e-commerce? An interactivity and vividness perspective", Journal of Interactive Marketing, Vol. 39, pp. 89-103.

Yim, M.Y.C. and Park, S.Y. (2019), "I am not satisfied with my body, so I like augmented reality (AR)': consumer responses to AR-based product presentations", Journal of Business Research, Vol. 100, pp. 581-589. 


\section{Appendix}

Questionnaire

\section{Relative advantage (Lou et al., 2017)}

- Using augmented reliability (AR) is beneficial to our company

- Using AR allows me to handle the customer more efficiently

- Using AR allows me to handle the customer easily

- Using AR is more useful for handling customer

\section{Compatibility (Lou et al., 2017)}

- $A R$ is compatible with my business

- Using AR fits well with the way I handle my customer

- Using AR to conduct business fits into my business dealing

\section{Complexity (Alam et al., 2018; Huang and Liao, 2015)}

- I think the AR application is easy

- I think it is very simple to learn how to use augmented reality application

- I think it does not require much effort to use an augmented reality application

\section{Observability (Lou et al., 2017)}

- I have difficulty telling others about the results of using AR

- I could communicate to others the consequences of using AR

- The results of using AR is apparent to me

\section{Trialability (Lou et al., 2017)}

- Before deciding on whether or not to adopt AR, I would be able to use it on a trial basis

- Before deciding on whether or not to adopt AR, I would be able to try it out properly

- I would be permitted to use AR on a trial basis long enough to see what it can do

Value alignment (Karahanna et al., 2006)

- Using augmented reality fits the way I view the world

- Using augmented reality fits my values about how to conduct online business

- Using augmented reality in keeping with my business values

\section{Cost (Alam et al., 2011)}

- The initial setup cost is high

- Incur extra cost for hiring IT staff

- Assessing cost and benefits is difficult 
Pressure from competitors (Wanyoike et al., 2012)

- Our competitors have adopted AR technology

- Our competitors are doing well in using AR technology

- Customers prefer online retailers who use AR technology

\section{Pressure from customers (Wainyoike et al., 2012)}

- Our customers expect us to use AR technology

- Our customers demand that we use AR technology

- The use of AR technology is something that would make the customer happy

\section{External support (Paydar et al., 2014)}

- The existing policy related to AR applications is quite suitable to support the adoption

- The government assists and supports the retail organizations to adopt AR application

\section{Behavioral intention (Authors proposition)}

- I intend to adopt AR in my business

- I think it will be worth it for me to adopt AR

- Soon regularly I will adopt AR

Table A1 Empirical literature in the augmented reality in tourism and entertainment industry

\begin{tabular}{|c|c|c|c|}
\hline Source & Context and country & $\begin{array}{l}\text { Methods/ } \\
\text { Sample }\end{array}$ & Variable found significant \\
\hline Cranmer et al. (2020) & AR in UK tourism & $\begin{array}{l}15 \text { Managers/ } \\
\text { Thematic }\end{array}$ & $\begin{array}{l}\text { Epistemic, marketing, tourist, } \\
\text { economic and organizational value }\end{array}$ \\
\hline Li et al. (2020) & $\begin{array}{l}\text { AR in Pokémon Go } \\
\text { games online }\end{array}$ & $\begin{array}{l}11,335 \\
\text { Participates }\end{array}$ & $\begin{array}{l}\text { Perceived benefits, satisfaction, } \\
\text { perceived risks }\end{array}$ \\
\hline Do et al. (2020) & $\begin{array}{l}\text { Mobile AR apps in } \\
\text { tourism }\end{array}$ & PLS-SEM/479 & Enjoyment, satisfaction \\
\hline $\begin{array}{l}\text { McLean and Wilson } \\
\text { (2019) }\end{array}$ & $\begin{array}{l}\text { AR in mobile applications } \\
\text { in the UK }\end{array}$ & $\begin{array}{l}\text { SPSS } / 441 \\
\text { consumers }\end{array}$ & Brand management \\
\hline Lee et al. (2019) & $\begin{array}{l}\text { AR in the entertainment } \\
\text { industry in South Korea }\end{array}$ & $\begin{array}{l}\text { SEM-AMOS/ } \\
350 \text { people }\end{array}$ & $\begin{array}{l}\text { Perceived usefulness, attitude, } \\
\text { perceived enjoyment }\end{array}$ \\
\hline $\begin{array}{l}\text { Rauschnabel et al. } \\
\text { (2017) }\end{array}$ & $\begin{array}{l}\text { AR in Pokémon Go } \\
\text { games in German }\end{array}$ & $\begin{array}{l}\text { SPSS/642 } \\
\text { players }\end{array}$ & $\begin{array}{l}\text { Social norms, benefits: flow, } \\
\text { socializing, image }\end{array}$ \\
\hline Shin (2019) & $\begin{array}{l}\text { AR in video games } \\
\text { around the world }\end{array}$ & $\begin{array}{l}\text { SEM/250 } \\
\text { participants }\end{array}$ & $\begin{array}{l}\text { Immersion, social presence, } \\
\text { confirmation, utility, hedonism, } \\
\text { satisfaction }\end{array}$ \\
\hline $\begin{array}{l}\text { Kourouthanassis } \\
\text { et al. (2015) }\end{array}$ & AR in tourist in Greece & $\begin{array}{l}\text { Smart-PLS/105 } \\
\text { tourist }\end{array}$ & $\begin{array}{l}\text { Pleasure, arousal, dominance, } \\
\text { personal innovativeness, price } \\
\text { value }\end{array}$ \\
\hline
\end{tabular}

Corresponding author

Syed Shah Alam can be contacted at: shahalam@ukm.edu.my

For instructions on how to order reprints of this article, please visit our website: www.emeraldgrouppublishing.com/licensing/reprints.htm

Or contact us for further details: permissions@emeraldinsight.com 